\title{
EFFECT OF SOME GROWTH RETARDANTS ON GROWTH AND FLOWERING OF HELIANTHUS ANNUUS L. CV. SUNRICH ORANGE SUMMER 981V PLANTS \\ A- EFFECT OF FOLIAR SPRAY TREATMENTS WITH ANCYMIDOL, DAMINOZIDE AND ETHEPHON
}

\author{
Azza M. Abdel-Moniem \\ Ornamental Plants and Landscape Gardening Res. Dept., Hort. Res. Inst., ARC, Giza, Egypt.
}

ABSTRACT: Pot experiments were carried out at the nursery of Hort. Res. Inst, Giza, Egypt throughout the two successive seasons of 2014 and 2015. The work embodied in this paper was to study the influence of some growth regulators (daminozide, ancymidol and ethephon) on sunflower (Helianthus annuus L. cv. Sunrich Orange Summer 981V) plant for achieving the hope of producing dwarf plant of good quality, suitable for using as a pot plant.

Results indicated that most treatments reduced stem length of the treated plants with the superiority of $2450 \mathrm{ppm}$ daminozide treatment which induced $50 \%$ reduction in such trait, compared to the control

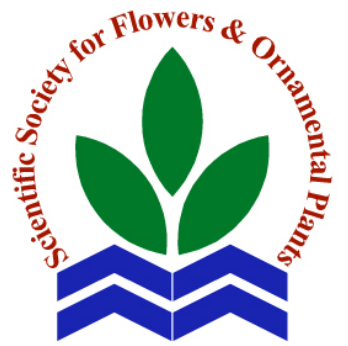

Scientific J. Flowers \& Ornamental Plants, 3(2):107-118 (2016).

Received: $1 / 6 / 2016$

Revised by: Prof. Dr. E.S. Nofal, Kafr El-Sheikh Univ.

Prof. Dr. A.Z. Sarhan, Cairo Univ. plants in the two seasons. However, stem diameter and number of internodes/stem were improved in response to all the used treatments. Internode length, stem fresh and dry weights were decreased with few exceptions, but the greatest decrease in these criteria was attained by daminozide treatment at any rate and ethephon one at $250 \mathrm{ppm}$. Number of leaves/plant were increased by the various treatments. Root length increased over control with few exceptions in both seasons. However, the highest averages in most measurements were achieved by ancymidol, especially at $20 \mathrm{ppm}$ level. A significant flowering earliness in the two seasons was noticed in plants sprayed with ethephon at $250 \mathrm{ppm}$. The least number of days from flower bud appearance to opening was obtained by the $20 \mathrm{ppm}$ ancymidol treatment, but the plants treated with the other treatments took longer time to anthesis. Ethephon treatments elevated the mean number of lateral buds/stem to the maximum, while ancymidol ones gave the largest flower heads. Number of ray flowers/head, disc diameter and flower head fresh and dry weights were improved due to most treatments. Content of photosynthetic pigments were slightly improved with few exceptions. Total phenols content reached the maximum by ancymidol treatments, followed by the ethephon ones. However, total indoles content was not affected by most of the used treatments. In addition, the percent of total soluble sugars was increased by ancymidol at $5 \mathrm{ppm}$, daminozide at $2450 \mathrm{ppm}$ and ethephon at 500 ppm treatments, while other treatments declined it. On the other hand, the percent of $\mathrm{N}, \mathrm{P}$ and $\mathrm{K}$ was generally decreased in response to the various treatments, with few exceptions as compared to control.

Key words: Sunflower (Helianthus annuus L.), growth retardants, dwarfing, ancymidol, daminozide, ethephon. 


\section{INTRODUCTION}

Sunflowers (Helianthus annuus L. cv. Sunrich Orange Summer 981V) family Asteraceae have a great potential as an ornamental plant because of their short growing cycle and easy propagation, but mainly because they have attractive inflorescences that are much sought after as cut flowers (Anefalos and Guilhoto, 2003).

Plant growth retardants are synthetic compounds used to retard the shoot length of plants in a desired way without changing developmental patterns or evoke phototoxic effect. This has been achieved not only by reducing cell elongation but also lowering the rate of cell division and regulating the plant height physiologically (Rademacher, 1995). Most plant growth retardants inhibit the formation of growth - active gibberellin $\left(\mathrm{GA}_{\mathrm{s}}\right)$ and can thus be used to reduce unwanted shoot elongation (Singh, 2004 and Mansuroglu et al., 2009). Growth retardants have also been noticed to increase the stress tolerance of plants during shipping, handling and rebial marketing thereby improving the shelf life, an important aspect in marketing practices (Latimer, 2001). Growth retardants control excessive vegetative growth that helps to adjust a perennial plant species to an annual cycle of cultivation for trimming hedges and trees.

The mode of action of plant growth retarding chemicals varies. Ancymidol (ARest; Sepro Crop, Carmel. Ind.) [acyclopropyl - a - (p-methyoxy-phenyl) - 5pyrimidinemethanol $\left.\left(\mathrm{C}_{15} \mathrm{H}_{16} \mathrm{~N}_{202}\right)\right]$ reduce stem elongation by inhibiting the Kaurene oxidation sequence of reactions in the gibberellins biosynthesis pathway (Gianfaga, 1995). Daminozide (B-Nine; Uniroyal Chemical Co.) [butonedioic acid mono (2,2dimethyl-hydrozide)] is reported to act by inhibiting translocation of gibberellins (Menhennet, 1980) and by increasing gibberellin degradation (Takeno et al., 1981). Ethephon (2-chloroethyl phosphonic acid) is an ethylene compound, and it is widely used a plant growth regulator. The effect of the application of Oxogenous gaseous ethylene or ethephon varies with plant species, chemical concentrations timing and duration of application. Ethephon regulates phases of plant growth and development by application to various growth sites (Kidd and James, 1991). Ethephon is used in the ornamental industry to delay flowering, selective to flower abortion, leaf abscision as well as to reduce stem elongation and increase stem strength (Basra, 2000). Briggs (1975) reported that stem and leaf length of Narcissus "Carlton" were effectively reduced by application of ethephon. However, sugars accumulation is promoted in tepals and pistil of tulip cv. Apeldoorn.

Concerning daminozide effect, various workers ascertained its beneficial effect in reducing plant height, suitable for different purposes. Ahmad et al. (2007) studied the effect of alar on Dianthus caryophyllus var. Red Sim for improving the production of compact plant. Two levels of hormone i.e. 200 and $400 \mathrm{mg} \mathrm{l}^{-1}$ were sprayed for the purpose. Dwarfness, number of branches and reduction in leaf area were directly correlated with the concentration of chemical. Also, alar decreased flower size considerably. George Kofidis et al. (2008) evaluated the effect of daminozide on certain growth characteristics of coriander (Coriander sativum L.). Daminozide was found effective on reducing stem elongation, that response varied with the concentration used (5000 or $1000 \mathrm{mg} \mathrm{l}^{-1}$ ). Daminozide had an insignificant effect on fresh weight and chlorophyll $\mathrm{a}$ and $\mathrm{b}$ content. Mushtaq et al. (2011) on Erysimum marchallii stated that B-nine application (500, 1000 and $1500 \mathrm{mg}$ $1^{-1}$ ) was not effective for decreasing plant height. The fresh and dry mass of roots, leaves and stem was decreased by the spray of B-nine. Also, B-nine applications slightly decreased the flowering yield and number of laterals. The flower diameter was slightly decreased by the spray application of B-nine. Reduced leaf area was the characteristic feature of the plants sprayed with B-nine. 
Several authors investigated the effect of ethephon on dwarfying of some plants and other morphological characters, Banon et al. (2003) experimented the effect of ethephon (ETH) to control the growth and development of the aerial part of Reichardia tingitana ETH $(25,50,75$ and $100 \mathrm{mg} / \mathrm{pot})$ doses. Results revealed that the most effective treatment was $100 \mathrm{mg} /$ pot for ETH, which reduced plant height by $50.3 \%$. ETH $(\geq 25 \mathrm{mg}$ ) significantly reduced plant width, aerial part dry weight, number of flowering stems and number of inflorescences per plant. ETH doses reduced inflorescence diameter. ETH $(\geq 50 \mathrm{mg})$ delayed the beginning of flowering.

Therefore, the work embodied in this paper was to study the influence of some growth regulators (daminozide, ancymidol and ethephon) on sunflower (Helianthus annuus L. cv. Sunrich Orange Summer $981 \mathrm{~V})$ plant for achieving the hope of producing dwarf plant of good quality, suitable for using as a potted plant.

\section{MATERIALS AND METHODS}

Pot experiments were carried out at the nursery of Hort. Res. Inst, Giza, Egypt throughout the two successive seasons of 2014 and 2015. The work embodied in this paper was to study the influence of some growth regulators (daminozide, ancymidol and ethephon) on sunflower (Helianthus annuus L. cv. Sunrich Orange Summer $981 \mathrm{~V}$ ) plant for achieving the hope of producing dwarf plant of good quality, suitable for using as a potted plant.
Seeds of annual sunflower (Helianthus annuus L. cv. Sunrich Orange Summer $981 \mathrm{~V}$, which is single-headed and has orange yellow ray florets with a black center, were imported from abroad by Floramax local commercial farm, El-Mansouria, Giza, Egypt), were sown on March, $30^{\text {th }}$ for each season, in $25-\mathrm{cm}$ diameter plastic pots (one seed/pot) filled with about $5 \mathrm{~kg}$ of sand and clay soil mixture at equal parts by volume $(1: 1 \mathrm{v} / \mathrm{v})$. The physical and chemical properties of the sand and clay used in the two seasons are shown in Table (a).

Germination of the seeds was complete 6 days after sowing and $15^{\text {th }}$ day after planting, plants showed two pairs of vegetative leaves.

\section{Experiment:}

In the experiment, three growth retardants, namely ancymidol at 0,5 and 20 ppm, dominozide (B-9) at 0.0, 1250 and $2450 \mathrm{ppm}$ and ethephon at 0.0, 250 and 500 ppm were sprayed 3 times with 2 weeks interval on the foliage till the run-off. Plants were arranged in a complete randomized design (7 treatments with 3 replicates. Each replicate contained 5 plants).

Control plants were sprayed with tap water. Plants under all treatments were fertilized through the course of the study with kristalon (19:19:19 + micronutrients) at the rate of $4 \mathrm{~g} / \mathrm{l}$ as a liquid drench application, alternatively with growth retardants spray treatments three times (the first one was added on April, $22^{\text {nd }}$ ) throughout the growth cycle of plants.

Table a. Physical and chemical properties of the used sand and clay in both seasons.

\begin{tabular}{|c|c|c|c|c|c|c|c|c|c|c|c|c|c|c|c|}
\hline \multirow{2}{*}{$\begin{array}{l}\text { Soil } \\
\text { type }\end{array}$} & \multirow{2}{*}{ 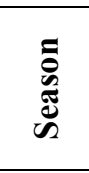 } & \multicolumn{4}{|c|}{$\begin{array}{c}\text { Particle size distribution } \\
(\%)\end{array}$} & \multirow{2}{*}{ S.P } & \multirow{2}{*}{$\begin{array}{l}\text { E.C. } \\
(\mathrm{ds} / \mathrm{m})\end{array}$} & \multirow{2}{*}{ pH } & \multicolumn{4}{|c|}{ Cations (meq/l) } & \multicolumn{3}{|c|}{ Anions (meq/l) } \\
\hline & & $\begin{array}{l}\text { Coars } \\
\text { e sand }\end{array}$ & $\begin{array}{l}\text { Fine } \\
\text { sand }\end{array}$ & Silt & Clay & & & & $\mathrm{Ca}^{++}$ & $\mathbf{M g}^{++}$ & $\mathbf{N a}^{+}$ & $\mathbf{K}^{+}$ & $\mathrm{HCO}_{3}^{-}$ & $\mathrm{Cl}^{-}$ & $\mathrm{SO}_{4}^{--}$ \\
\hline \multirow{2}{*}{$\begin{array}{l}\text { Sandy } \\
\text { soil }\end{array}$} & 2014 & 89.03 & 2.05 & 0.40 & 8.52 & 23.01 & 3.56 & 7.90 & 7.50 & 1.63 & 33.60 & 0.50 & 3.20 & 22.00 & 18.03 \\
\hline & 2015 & 84.76 & 6.29 & 1.50 & 7.45 & 21.87 & 3.71 & 7.80 & 19.42 & 8.33 & .20 & 0.75 & 1.60 & 7.80 & 26.30 \\
\hline \multirow{2}{*}{$\begin{array}{c}\text { Loamy } \\
\text { soil }\end{array}$} & 2014 & 10.18 & 46.17 & 19.53 & 24.12 & 35.00 & 3.48 & 8.27 & 17.50 & 9.42 & 20.00 & 0.79 & 3.80 & 10.00 & 33.91 \\
\hline & 2015 & 10.30 & 46.54 & 18.88 & 24.28 & 33.07 & 3.36 & 7.96 & 18.00 & 8.95 & 20.50 & 0.85 & 3.65 & 10.20 & 34.45 \\
\hline
\end{tabular}




\section{Data recorded at the end of experiment:}

Plants in each treatment were observed daily until the first flower bud appeared:

- Stem length (cm)

- Stem diameter (cm)

- Number of internodes/stem

- Internodes length $(\mathrm{cm})$

- Stem fresh and dry weights (g)

- Number of leaves/plant

- Leaf length and width $(\mathrm{cm})$

- leaves fresh and dry weights $(\mathrm{g})$

- Root length $(\mathrm{cm})$

- Roots fresh and dry weights (g)

- Number of days to flower bud appear once (days)

- Number of days to flower bud opening (days)

- Number of days from flower bud appear to opening once (days)

- Number of lateral buds/stem

- Flower head diameter $(\mathrm{cm})$

- Number of ray flowers per head

- Disc diameter $(\mathrm{cm})$

- Ray flower length (cm)

- Flower heads fresh and dry weights (g)

In fresh leaf samples, the photosynthetic pigments content (chlorophyll a, b and carotenoids), total phenols, total indoles and total soluble sugars were evaluated according to the methods of Yadava (1986), William et al. (1965), A.O.A.C. (1990) and Dubois et al. (1966), respectively; In dry leaf samples the percentages of nitrogen (Pregl, 1945), phosphorus (Luatanab and Olsen, 1965) and potassium (Jackson, 1973) were evaluated.

Data were tabulated and submitted to analysis of variance using program of SAS Institute (2009) and the differences among the means of treatments were determined with respect to their homogeneity by
Duncan's New Multiple Range Test (Steel and Torrie, 1980) at $5 \%$ level.

\section{RESULTS AND DISCUSSION}

\section{1- Effect on vegetative and root growth parameters:}

Table (1) indicates that most treatments shortened stem length of sprayed plants with the supremacy of daminozide spray at 2450 ppm which reduced the mean of this trait to 32.83 and $33.00 \mathrm{~cm}$ versus 64.25 and 63.58 $\mathrm{cm}$ for the control plants in the $1^{\text {st }}$ and $2^{\text {nd }}$ seasons, respectively (about $50 \%$ reduction), followed by spraying with ethephon at 500 ppm that caused about $45 \%$ reduction in this parameter. This may be due to daminozide which renders a key enzyme for GA production useless, at the end of the GA production process, thus reducing GA levels, while ethephon does not inhibit GA production. Plants takeup ethrel through the leaves and convert it to ethylene in plant cells. The increased ethylene level causes cells to limit elongation and increase width instead (Currey and Lopez, 2008). In this regard, Kazaz et al. (2010) stated that applying daminozide solutions to the substrate, is ineffective. In Chrysanthemum Similar effects were also obtained by Sabbagh et al. (2008) and Cuquel et al. (2010) on sunflower, Warner and Erwin (2003) on Hibiscus spp. and Krause et al. (2003) who revealed that spraying the foliage of Tagetes patula, Impatiens walleriana and Petunia hybrida with daminozide at $1275 \mathrm{ppm}$, twice inhibited growth and stimulated flowering. This was emphasized by Amling et al. (2005) who mentioned that daminozide (B-9) was more effective in controlling height of Coreopsis verticillata "Moonbeam" and Rudbeckia fulgida "Goldsturm", than cycocel. Moreover, Khuankaew et al. (2009) elicited that application of ethrel as drenching at 300 and $500 \mathrm{ppm}$ concentrations decreased plant height of Curcuma alismatifolia rhizomatus plants, but did not affect the rhizome size (width and length). 
Table 1. Effect of growth retardants spraying on stem parameters of Helianthus annuus L. cv. Sunrich Orange Summer-981V plants during 2014 and 2015 seasons.

\begin{tabular}{|c|c|c|c|c|c|c|}
\hline Treatments & $\begin{array}{l}\text { Stem length } \\
(\mathrm{cm})\end{array}$ & $\begin{array}{c}\text { Stem diameter } \\
(\mathrm{cm})\end{array}$ & $\begin{array}{c}\text { No. of } \\
\text { internodes per } \\
\text { stem }\end{array}$ & $\begin{array}{l}\text { Internode } \\
\text { length }(\mathrm{cm})\end{array}$ & Stem f.w. (g.) & Stem d.w. (g) \\
\hline & \multicolumn{6}{|c|}{ First season: 2014} \\
\hline Control & $64.25 \mathrm{ab}$ & $0.53 \mathrm{c}$ & $12.00 \mathrm{~b}$ & $5.77 \mathrm{a}$ & $24.67 \mathrm{ab}$ & $4.45 b$ \\
\hline Ancy 5 ppm & $59.33 \mathrm{bc}$ & $0.68 \mathrm{ab}$ & $13.00 \mathrm{ab}$ & $4.43 a-c$ & $21.51 \mathrm{ab}$ & $4.18 b$ \\
\hline Ancy 20 ppm & $75.00 \mathrm{a}$ & $1.08 \mathrm{a}$ & $15.00 \mathrm{a}$ & $5.65 a$ & $71.57 \mathrm{a}$ & $13.13 \mathrm{a}$ \\
\hline Dmz 1250 ppm & $51.33 \mathrm{bc}$ & $0.80 \mathrm{ab}$ & $12.00 \mathrm{~b}$ & $3.36 \mathrm{bc}$ & $32.60 \mathrm{ab}$ & $6.05 \mathrm{ab}$ \\
\hline Dmz 2450 ppm & $32.83 \mathrm{~d}$ & $0.80 \mathrm{ab}$ & $9.50 \mathrm{c}$ & $3.03 \mathrm{c}$ & $17.24 \mathrm{ab}$ & $2.67 \mathrm{~b}$ \\
\hline Eth 250 ppm & $45.17 \mathrm{~cd}$ & $0.60 \mathrm{~b}$ & $12.17 \mathrm{~b}$ & $3.32 \mathrm{bc}$ & $13.92 b$ & $2.38 \mathrm{~b}$ \\
\hline \multirow[t]{2}{*}{ Eth 500 ppm } & $35.83 d$ & $0.72 \mathrm{ab}$ & $11.17 \mathrm{bc}$ & $4.90 \mathrm{ab}$ & $22.97 \mathrm{ab}$ & $3.03 \mathrm{~b}$ \\
\hline & \multicolumn{6}{|c|}{ Second season: 2015} \\
\hline Control & $63.58 \mathrm{a}$ & $0.52 b$ & $10.67 \mathrm{c}$ & $5.12 \mathrm{a}-\mathrm{c}$ & $18.60 \mathrm{ab}$ & $3.29 \mathrm{a}-\mathrm{c}$ \\
\hline Ancy 5 ppm & $61.67 \mathrm{a}$ & $0.58 \mathrm{~b}$ & $14.33 \mathrm{a}$ & $6.12 \mathrm{a}$ & $17.29 b$ & $3.13 b c$ \\
\hline Ancy 20 ppm & $73.25 \mathrm{a}$ & $0.96 \mathrm{a}$ & $13.17 \mathrm{ab}$ & $6.42 \mathrm{a}$ & $60.64 a$ & $11.07 \mathrm{a}$ \\
\hline Dmz 1250 ppm & $41.17 \mathrm{bc}$ & $0.63 b$ & $11.00 \mathrm{c}$ & $3.60 \mathrm{~cd}$ & $11.93 b$ & $1.92 \mathrm{c}$ \\
\hline Dmz 2450 ppm & $33.00 \mathrm{c}$ & $0.90 \mathrm{a}$ & $10.67 \mathrm{c}$ & $3.76 \mathrm{~cd}$ & $17.75 b$ & $3.16 \mathrm{ab}$ \\
\hline Eth 250 ppm & $46.17 b$ & $0.67 b$ & $12.33 \mathrm{bc}$ & $3.31 \mathrm{~d}$ & $17.16 b$ & $3.19 b c$ \\
\hline Eth 500 ppm & $35.25 \mathrm{bc}$ & $0.60 \mathrm{~b}$ & $11.17 \mathrm{c}$ & $4.08 \mathrm{~b}-\mathrm{d}$ & $17.95 \mathrm{~b}$ & $2.93 \mathrm{bc}$ \\
\hline
\end{tabular}

*Ancy $=$ Ancymidol,Dmz=Daminozide and Eth $=$ Ethephon

*Means within a column having the same letters are not significantly different according to Duncan's New Multiple Range Test at $5 \%$ level.

Concerning stem diameter and number of internodes/stem, means of these two characters improved in response to the different treatments employed, with the mastery of 20 ppm ancymidol, which scored the utmost high averages in the two seasons over all other treatments. The sole exception in these two traits is that daminozide treatment at $2450 \mathrm{ppm}$ induced a significant reduction in number of internodes/stem in the first season, while in the second one, records were equal to that of control plants. On the other hand, a reduction was obtained in internode length and stem fresh and dry weights, with few exceptions, compared to control plants in the two seasons. However, the greatest reduction in such criteria was a result of spraying with either daminozide at 1250 or $2450 \mathrm{ppm}$ or ethephon at $250 \mathrm{ppm}$, as these treatments gave the shortest internodes and the lightest stem fresh and dry weights in most instances of both seasons. Decreasing number of internode/stem and the length of internode by daminozide treatments may be reasonable due to the production of stunted plants.
In relation to leaf parameters, data presented in Table (2) show that number of leaves/plant increased by all treatments applied in this trial with various significant differences relative to the control plants in both seasons. The greatest number was obtained in the first season by spraying ancymidol at $5 \mathrm{ppm}$ followed by spraying at $20 \mathrm{ppm}$ ancymidol, $1250 \mathrm{ppm}$ daminozide and $500 \mathrm{ppm}$ ethephon solutions, while in the second season, that was established by 20 ppm ancymidol treatment, followed by 500 ppm ethephon one. On the other side, means of leaf length and width, as well as leaves fresh and dry weights fluctuated with nonsignificant differences compared to the control plants, in most instances of the two seasons. However, the highest records were recorded in both seasons by $20 \mathrm{ppm}$ ancymidol treatment, whereas the least ones were found due to spraying with ethephon at $250 \mathrm{ppm}$.

It was noticed that the longest root was achieved in the $1^{\text {st }}$ season by treating plants with ancymidol at any rate and ethephon at 250 ppm (Table, 3 ) while in the $2^{\text {nd }}$ one, that was attained by either $20 \mathrm{ppm}$ ancymidol or 
Table 2. Effect of growth retardants spraying on leaf parameters of Helianthus annuus L. cv. Sunrich Orange Summer-981V plants during 2014 and 2015 seasons.

\begin{tabular}{lccccc}
\hline \multicolumn{1}{c}{ Treatments } & $\begin{array}{c}\text { Number of } \\
\text { leaves/plant }\end{array}$ & $\begin{array}{c}\text { Leaf length } \\
(\mathbf{c m})\end{array}$ & $\begin{array}{c}\text { Leaf width } \\
\text { (cm) }\end{array}$ & $\begin{array}{c}\text { Leaves } \\
\text { f.w. (g) }\end{array}$ & $\begin{array}{c}\text { Leaves } \\
\text { d.w. (g) }\end{array}$ \\
\hline Control & & & First season: 2014 & & \\
Ancy 5 ppm & $13.83 \mathrm{~cd}$ & $9.75 \mathrm{bc}$ & $6.47 \mathrm{bc}$ & $16.24 \mathrm{ab}$ & $2.48 \mathrm{~b}$ \\
Ancy 20 ppm & $19.67 \mathrm{a}$ & $9.72 \mathrm{bc}$ & $9.42 \mathrm{bc}$ & $13.87 \mathrm{ab}$ & $2.62 \mathrm{~b}$ \\
Dmz 1250 ppm & $17.17 \mathrm{ab}$ & $12.67 \mathrm{a}$ & $10.28 \mathrm{a}$ & $46.01 \mathrm{a}$ & $9.24 \mathrm{a}$ \\
Dmz 2450 ppm & $17.33 \mathrm{ab}$ & $10.20 \mathrm{~b}$ & $7.67 \mathrm{~b}$ & $29.14 \mathrm{ab}$ & $4.63 \mathrm{ab}$ \\
Eth 250 ppm & $14.67 \mathrm{bc}$ & $9.33 \mathrm{bc}$ & $6.52 \mathrm{bc}$ & $17.41 \mathrm{ab}$ & $2.96 \mathrm{ab}$ \\
Eth 500 ppm & $14.17 \mathrm{c}$ & $8.30 \mathrm{c}$ & $5.72 \mathrm{c}$ & $9.59 \mathrm{~b}$ & $1.88 \mathrm{~b}$ \\
& $17.17 \mathrm{ab}$ & $9.66 \mathrm{bc}$ & $6.47 \mathrm{bc}$ & $15.93 \mathrm{ab}$ & $2.62 \mathrm{ab}$ \\
Control & & & Second season: 2015 & & $1.97 \mathrm{~b}$ \\
Ancy 5 ppm & $13.67 \mathrm{~d}$ & $9.98 \mathrm{ab}$ & $6.82 \mathrm{ab}$ & $12.11 \mathrm{ab}$ & $1.64 \mathrm{~b}$ \\
Ancy 20 ppm & $15.83 \mathrm{~b}-\mathrm{d}$ & $9.22 \mathrm{~b}$ & $5.78 \mathrm{~b}$ & $9.87 \mathrm{~b}$ & $7.94 \mathrm{a}$ \\
Dmz 1250 ppm & $19.50 \mathrm{a}$ & $11.42 \mathrm{a}$ & $8.97 \mathrm{a}$ & $43.80 \mathrm{a}$ & $2.11 \mathrm{~b}$ \\
Dmz 2450 ppm & $14.33 \mathrm{c}-\mathrm{d}$ & $9.27 \mathrm{~b}$ & $6.60 \mathrm{~b}$ & $12.62 \mathrm{ab}$ & $3.54 \mathrm{ab}$ \\
Eth 250 ppm & $17.00 \mathrm{a}-\mathrm{c}$ & $9.50 \mathrm{ab}$ & $6.90 \mathrm{ab}$ & $23.01 \mathrm{a}$ & $2.28 \mathrm{~b}$ \\
Eth 500 ppm & $15.00 \mathrm{~cd}$ & $8.75 \mathrm{~b}$ & $5.95 \mathrm{~b}$ & $12.60 \mathrm{ab}$ & $2.51 \mathrm{~b}$ \\
\hline
\end{tabular}

*Ancy =Ancymidol,Dmz=Daminozide and Eth=Ethephon

*Means within a column having the same letters are not significantly different according to Duncan's New Multiple Range Test at $5 \%$ level.

Table 3. Effect of growth retardants spraying on root parameters of Helianthus annuus L. cv. Sunrich Orange Summer-981V plants during 2014 and 2015 seasons.

\begin{tabular}{lcccccc}
\hline \multicolumn{2}{c}{ Treatments } & \multicolumn{2}{c}{ Root length $\mathbf{( c m )}$} & \multicolumn{2}{c}{ Roots f.w. (g) } & \multicolumn{2}{c}{ Roots d.w. (g) } \\
& $\mathbf{2 0 1 4}$ & $\mathbf{2 0 1 5}$ & $\mathbf{2 0 1 4}$ & $\mathbf{2 0 1 5}$ & $\mathbf{2 0 1 4}$ & $\mathbf{2 0 1 5}$ \\
\hline Control & $17.67 \mathrm{ab}$ & $15.00 \mathrm{bc}$ & $19.70 \mathrm{a}$ & $13.08 \mathrm{a}$ & $3.82 \mathrm{a}$ & $2.64 \mathrm{a}$ \\
Ancy 5 ppm & $21.08 \mathrm{a}$ & $18.58 \mathrm{ab}$ & $14.40 \mathrm{a}$ & $10.04 \mathrm{a}$ & $4.29 \mathrm{a}$ & $2.13 \mathrm{a}$ \\
Ancy 20 $\mathbf{~ p p m}$ & $24.82 \mathrm{a}$ & $26.42 \mathrm{a}$ & $23.32 \mathrm{a}$ & $17.15 \mathrm{a}$ & $9.06 \mathrm{a}$ & $4.39 \mathrm{a}$ \\
Dmz 1250 ppm & $12.00 \mathrm{~b}$ & $12.50 \mathrm{c}$ & $11.63 \mathrm{a}$ & $11.49 \mathrm{a}$ & $2.83 \mathrm{a}$ & $2.07 \mathrm{a}$ \\
Dmz 2450 $\mathbf{~ p p m}$ & $17.50 \mathrm{ab}$ & $20.83 \mathrm{a}$ & $14.18 \mathrm{a}$ & $15.32 \mathrm{a}$ & $3.08 \mathrm{a}$ & $3.57 \mathrm{a}$ \\
Eth 250 ppm & $21.83 \mathrm{a}$ & $15.00 \mathrm{bc}$ & $11.17 \mathrm{a}$ & $15.81 \mathrm{a}$ & $3.79 \mathrm{a}$ & $3.22 \mathrm{a}$ \\
Eth 500 ppm & $19.25 \mathrm{ab}$ & $13.75 \mathrm{bc}$ & $16.94 \mathrm{a}$ & $13.52 \mathrm{a}$ & $5.43 \mathrm{a}$ & $3.35 \mathrm{a}$ \\
\hline
\end{tabular}

*Ancy =Ancymidol,Dmz=Daminozide and Eth=Ethephon

*Means within a column having the same letters are not significantly different according to Duncan's New Multiple Range Test at $5 \%$ level.

$2450 \mathrm{ppm}$ daminozide treatments. Means of roots fresh and dry weights declined generally, with few exceptions as a result of the various growth retardants used in the current study, with non-significant differences when compared to control means in the two seasons. Spraying with ancymidol at $20 \mathrm{ppm}$ was the only treatment that recorded the heaviest fresh and dry weights compared to all other treatments in both seasons as the highest number of leaves were scored by this treatment.
The aforementioned gains could be interpreted and discussed as done before in case of stem length trait.

\section{2- Effect on flowering parameters:}

It is obvious from data registered in Table (4) that ethephon treatment at $250 \mathrm{ppm}$ caused a significant precocity in flowering of treated plants compared to those of untreated ones, as it reduced the number of days to flower bud appearance to 46.67 and 45.67 days, against 53.00 and 53.33 days for the 
Table 4. Effect of growth retardants spraying on number of days to flower bud appear and opening of Helianthus annuus L. cv. Sunrich Orange Summer-981V plants during 2014 and 2015 seasons.

\begin{tabular}{lcccccc}
\hline \multicolumn{1}{c}{ Treatments } & \multicolumn{2}{c}{$\begin{array}{c}\text { No. of days to flower bud } \\
\text { appearance (days) }\end{array}$} & \multicolumn{2}{c}{$\begin{array}{c}\text { No. of days to flower bud } \\
\text { opening (days) }\end{array}$} & \multicolumn{2}{c}{$\begin{array}{c}\text { No. of days from flower bud } \\
\text { appearance to opening (days) }\end{array}$} \\
& $\mathbf{2 0 1 4}$ & $\mathbf{2 0 1 5}$ & $\mathbf{2 0 1 4}$ & $\mathbf{2 0 1 5}$ & $\mathbf{2 0 1 4}$ & $\mathbf{2 0 1 5}$ \\
\hline Control & $53.00 \mathrm{a}$ & $53.33 \mathrm{a}$ & $66.00 \mathrm{ab}$ & $65.83 \mathrm{bc}$ & $15.33 \mathrm{a}-\mathrm{c}$ & $15.17 \mathrm{a}-\mathrm{c}$ \\
Ancy 5 ppm & $50.00 \mathrm{ab}$ & $49.00 \mathrm{bc}$ & $64.00 \mathrm{~b}$ & $64.83 \mathrm{c}$ & $14.00 \mathrm{~b}-\mathrm{c}$ & $18.83 \mathrm{a}-\mathrm{c}$ \\
Ancy 20 ppm & $50.67 \mathrm{ab}$ & $50.67 \mathrm{ab}$ & $66.33 \mathrm{ab}$ & $66.33 \mathrm{a}-\mathrm{c}$ & $13.33 \mathrm{c}$ & $13.00 \mathrm{c}$ \\
Dmz 1250 ppm & $47.67 \mathrm{ab}$ & $49.00 \mathrm{bc}$ & $66.33 \mathrm{ab}$ & $68.33 \mathrm{ab}$ & $18.64 \mathrm{a}$ & $19.33 \mathrm{a}$ \\
Dmz 2450 ppm & $52.50 \mathrm{ab}$ & $52.67 \mathrm{a}$ & $67.00 \mathrm{ab}$ & $68.33 \mathrm{ab}$ & $14.50 \mathrm{bc}$ & $15.33 \mathrm{bc}$ \\
Eth 250 ppm & $46.67 \mathrm{~b}$ & $45.67 \mathrm{c}$ & $64.67 \mathrm{~b}$ & $64.00 \mathrm{c}$ & $18.00 \mathrm{ab}$ & $18.33 \mathrm{ab}$ \\
Eth 500 $\mathbf{~ p p m}$ & $51.83 \mathrm{ab}$ & $51.67 \mathrm{ab}$ & $68.67 \mathrm{a}$ & $69.00 \mathrm{a}$ & $16.83 \mathrm{a}-\mathrm{c}$ & $16.50 \mathrm{ab}$ \\
\hline
\end{tabular}

*Ancy =Ancymidol,Dmz=Daminozide and Eth=Ethephon

* Means within a column having the same letters are not significantly different according to Duncan's New Multiple Range Test at $5 \%$ level.

control plants in the first and second seasons, respectively. A similar trend was obtained by $5 \mathrm{ppm}$ ancymidol and $1250 \mathrm{ppm}$ daminozide treatments in the second season only $(49.00$ days for each). However, all other treatments gave means closely near to those of the control plants with non-significant differences among themselves in the two seasons. Likewise, the least number of days to flower bud opening was recorded by 250 ppm ethephon spraying treatment along with $5 \mathrm{ppm}$ ancymidol sprayin in the two seasons. However, the least number days passed from flower bud appearance to opening was attained by spraying with ancymidol at 20 ppm. Plants treated subjected to other treatments took longer times to anthesis compared with the control plants in both seasons. These observations are in accordance with those of Kessler and Keever (2007) who found that number of days from treatment to first flower open in Coreopsis verticillata "Moonbeam" plants increased linearly with increasing daminozide rate. Meanwhile Warner and Erwin (2003) noted that daminozide ( 2500 or $5000 \mathrm{ppm}$ ) did not delay flowering of Hibiscus trionum plants. Dole and Wilkins (1999) mentioned that growth retardants are still commercially used to inhibit stem elongation, enhance foliage colour and decrease time to flower.
The mean number of lateral buds/stem (Table, 5) was improved in both seasons by spraying with either, ancymidol or ethephon at any rate. However, the dominance was for ethephon treatments which elevated the means of this character to the maximal values in the $1^{\text {st }}$ and $2^{\text {nd }}$ seasons. This may be attributed to the role of ethephon in reducing the apical dominance, which can increase axillary budding and branching (Currey and Lopez, 2008). The ancymidol treatments at 5 and $20 \mathrm{ppm}$ rates were the only treatments that significantly increased flower head diameter over the control plants and other treatments in most instances of both seasons, whereas daminozide and ethephon treatments at any rate decreased it with various significance levels, relative to control plants in the two seasons. A similar trend was also obtained concerning ray flower length. This may be ascribed to various active ingredients in the chemicals used. The opposite was the right in relation to number ray flowers / head, disc diameter and flower head fresh and dry weights parameters, as their means were improved, with few exceptions due to the different treatments compared to control means in the two seasons. Similar effects of chemicals used in the current study were reported by Whipker et al. (2004), Bonacin et al. (2006) 
Table 5. Effect of growth retardants spraying on flowering parameters of Helianthus annuus L. cv. Sunrich Orange Summer-981V plants during 2014 and 2015 seasons.

\begin{tabular}{|c|c|c|c|c|c|c|c|}
\hline \multirow{2}{*}{ Treatments } & \multirow{2}{*}{$\begin{array}{c}\text { No. of } \\
\text { lateral } \\
\text { buds/stem }\end{array}$} & \multirow{2}{*}{$\begin{array}{c}\text { Flower head } \\
\text { diameter } \\
(\mathrm{cm})\end{array}$} & \multirow{2}{*}{$\begin{array}{l}\text { No. of ray } \\
\text { flowers per } \\
\text { head }\end{array}$} & \multirow{2}{*}{$\begin{array}{c}\text { Disc } \\
\text { diameter } \\
(\mathrm{cm})\end{array}$} & \multirow{2}{*}{$\begin{array}{l}\text { Ray flower } \\
\text { length }(\mathrm{cm})\end{array}$} & \multicolumn{2}{|c|}{ Flower heads } \\
\hline & & & & & & f.w. (g) & d.w. (g) \\
\hline & \multicolumn{7}{|c|}{ First season: 2014} \\
\hline Control & $0.00 \mathrm{~b}$ & $12.27 \mathrm{ab}$ & $23.17 b$ & $3.40 \mathrm{ab}$ & $8.87 \mathrm{ab}$ & $17.40 \mathrm{a}$ & $2.58 \mathrm{~b}$ \\
\hline Ancy 5 ppm & $1.00 \mathrm{ab}$ & $13.63 \mathrm{a}$ & $29.50 \mathrm{ab}$ & $3.68 \mathrm{ab}$ & $10.07 \mathrm{a}$ & $20.06 \mathrm{a}$ & $3.76 \mathrm{ab}$ \\
\hline Ancy 20 ppm & $1.00 \mathrm{ab}$ & $13.75 \mathrm{a}$ & $32.00 \mathrm{ab}$ & $4.80 \mathrm{a}$ & $8.83 \mathrm{ab}$ & $26.50 \mathrm{a}$ & $8.22 \mathrm{a}$ \\
\hline Dmz 1250 ppm & $0.00 \mathrm{~b}$ & $11.17 \mathrm{a}-\mathrm{c}$ & $29.33 \mathrm{ab}$ & $3.63 \mathrm{ab}$ & $7.53 \mathrm{bc}$ & $22.82 \mathrm{a}$ & $3.61 \mathrm{ab}$ \\
\hline Dmz 2450 ppm & $0.00 \mathrm{~b}$ & $9.45 b c$ & $30.00 \mathrm{ab}$ & $3.02 b$ & $6.43 b-d$ & $14.60 \mathrm{a}$ & $2.56 \mathrm{~b}$ \\
\hline Eth 250 ppm & $2.17 \mathrm{a}$ & $8.45 \mathrm{c}$ & $25.50 \mathrm{~b}$ & $3.42 \mathrm{ab}$ & $5.03 \mathrm{~d}$ & $16.27 \mathrm{a}$ & $2.54 \mathrm{~b}$ \\
\hline \multirow[t]{2}{*}{ Eth 500 ppm } & $1.17 \mathrm{ab}$ & $9.41 b c$ & $35.50 \mathrm{a}$ & $3.07 \mathrm{~b}$ & $6.35 \mathrm{~cd}$ & $14.79 \mathrm{a}$ & $2.17 \mathrm{~b}$ \\
\hline & \multicolumn{7}{|c|}{ Second season: 2015} \\
\hline Control & $0.00 \mathrm{~b}$ & $10.28 b$ & $23.67 b$ & $3.12 b$ & $7.17 \mathrm{~b}$ & $14.48 b$ & $2.09 \mathrm{~b}$ \\
\hline Ancy 5 ppm & $1.00 \mathrm{ab}$ & $12.75 \mathrm{a}$ & $25.00 \mathrm{~b}$ & $3.37 \mathrm{~b}$ & $9.77 \mathrm{a}$ & $15.29 b$ & $2.45 b$ \\
\hline Ancy 20 ppm & $1.67 \mathrm{ab}$ & $13.92 \mathrm{a}$ & $27.50 \mathrm{ab}$ & $4.48 \mathrm{a}$ & $9.70 \mathrm{a}$ & $23.43 \mathrm{a}$ & $7.64 \mathrm{a}$ \\
\hline Dmz 1250 ppm & $0.67 \mathrm{ab}$ & $10.30 \mathrm{~b}$ & $26.17 b$ & $3.17 \mathrm{~b}$ & $7.23 b$ & $17.94 \mathrm{~b}$ & $2.52 \mathrm{~b}$ \\
\hline Dmz 2450 ppm & $0.00 \mathrm{~b}$ & $10.25 b$ & $33.00 \mathrm{a}$ & $3.42 \mathrm{~b}$ & $8.83 b$ & $20.20 \mathrm{ab}$ & $3.12 \mathrm{ab}$ \\
\hline Eth 250 ppm & $1.83 \mathrm{a}$ & $9.62 b$ & $26.83 \mathrm{ab}$ & $3.32 b$ & $6.30 \mathrm{~b}$ & $18.89 \mathrm{ab}$ & $2.80 \mathrm{~b}$ \\
\hline Eth 500 ppm & $2.00 \mathrm{a}$ & $9.33 b$ & $30.33 \mathrm{ab}$ & $3.07 \mathrm{~b}$ & $6.27 b$ & $14.43 b$ & $2.48 \mathrm{~b}$ \\
\hline
\end{tabular}

*Ancy =Ancymidol,Dmz=Daminozide and Eth=Ethephon

*Means within a column having the same letters are not significantly different according to Duncan's New Multiple Range Test at $5 \%$ level.

and Giuffrida et al. (2009) on sunflower cvs. In this connection, Krause et al. (2003) decided that daminozide at either $1275 \mathrm{ppm}$ (drench) + 1275 ppm (spray) or $1275 \mathrm{ppm}$ (drench) $+2550 \mathrm{ppm}$ (spray) significantly increased number of flower buds and number of flowers/inflorescence in the treated plants of Petunia hybrida "Bravo Pink".

\section{3- Effect on chemical composition of the leaves:}

It is evident from data averaged in Table (6) that the content of chlorophyll a, b and carotenoids in the leaves was slightly improved, with few exceptions, compared to the same contents in leaves of control plants. The highest content of total phenols was induced by ancymidol treatments at either 5 or $20 \mathrm{ppm}$, with the superiority of the latter concentration (1.39 ppm vs. 0.19 ppm for the control plants), followed by ethephon treatment, that doubled the phenol content in treated plants compared to control ones. Total indoles content, however was unaffected pronouncedly by the used treatments, except for ethephon treatments, that induced a slight increment in content of such constituent. The percent of total soluble sugars recorded in Table (7) show that this active component only increased by $5 \mathrm{ppm}$ ancymidol, $500 \mathrm{ppm}$ ethephon treatments and $2450 \mathrm{ppm}$ daminozide compared to the control plants, while other treatments declined it. On the other hand, a reduction was observed in the percent of nitrogen, phosphorus and potassium, due to the other used treatments, with few exceptions compared to their percentages in the control leaves.

From the aforementioned results, it is recommended to use $2450 \mathrm{ppm}$ daminozide spray treatment to obtain proper midget sunflower plants with solitary stem carrying a good number of natural-sized leaves and a single flower head full of ray florets.

\section{REFERENCES}

Ahmad, I.; Ziaf, K.; Qasim, M. and Tariq, M. (2007). Comparative evoluation of different pinching approaches on vegetative and reproductive growth of carnation. Pak. J. Agric. Sci., 44(4):563570. 
Table 6. Effect of growth retardants spraying on pigments, total phenols and total indoles contents in the leaves of Helianthus annuus L. cv. Sunrich Orange Summer-981V plants during 2014 and 2015 seasons.

\begin{tabular}{lccccc}
\hline \multicolumn{1}{c}{ Treatments } & \multicolumn{3}{c}{ Pigments content (mg/g. f.w) } & Total phenols & Total indoles \\
& Chlorophyll (a)Chlorophyll (b) & Carotenoids & (ppm) & (ppm) \\
\hline Control & 1.19 & 0.42 & 0.24 & 0.19 & 0.08 \\
Ancy 5 ppm & 1.17 & 0.41 & 0.25 & 0.86 & 0.07 \\
Ancy 20 ppm & 1.26 & 0.43 & 0.18 & 1.39 & 0.07 \\
Dmz 1250 ppm & 1.24 & 0.44 & 0.22 & 0.22 & 0.08 \\
Dmz 2450 ppm & 1.36 & 0.48 & 0.23 & 0.16 & 0.08 \\
Eth 250 ppm & 1.48 & 0.53 & 0.23 & 0.37 & 0.09 \\
Eth 500 ppm & 1.14 & 0.47 & 0.19 & 0.38 & 0.11 \\
\hline
\end{tabular}

*Ancy $=$ Ancymidol,Dmz=Daminozide and Eth=Ethephon

Table 7. Effect of growth retardants spraying on total soluble sugars, $N, P$ and $K \%$ in the leaves of Helianthus annuus L. cv. Sunrich Orange Summer-981V plants during 2014 and 2015 seasons.

\begin{tabular}{lcccc}
\hline \multicolumn{1}{c}{ Treatments } & $\begin{array}{c}\text { Total soluble } \\
\text { sugars (\%) }\end{array}$ & N (\%) & P (\%) & K (\%) \\
Control & 1.23 & 1.74 & 0.40 & 1.76 \\
Ancy 5 ppm & 3.76 & 1.62 & 0.58 & 1.38 \\
Ancy 20 ppm & 0.98 & 1.33 & 0.33 & 1.96 \\
Dmz 1250 ppm & 0.75 & 1.43 & 0.35 & 1.53 \\
Dmz 2450 ppm & 1.89 & 1.34 & 0.37 & 1.56 \\
Eth 250 ppm & 0.79 & 1.17 & 0.54 & 0.55 \\
Eth 500 ppm & 3.34 & 1.41 & 0.33 & 1.39 \\
\hline
\end{tabular}

*Ancy $=$ Ancymidol,Dmz=Daminozide and Eth=Ethephon

Amling, J.W.; Keever, G.J.; Kessler, J.R. and Eakes, D.J. (2005). Response of "Moonbeam" Coreopsis and "Goldsturm" Rudbeckia to B-9 and cycocel. J. Environ. Hort., 23(1):25-28.

Anefalos, L.C. and Guilhoto, J.J. (2003). Estrudura do Mercado brasileiro de flores e plantas ornamentais. Agricultura em São Paulo, 50(2):41-63.

A.O.A.C. (1990). Association of Official Agricultural Chemists. "Official Methods of Analysis of the Association of Official Agricultural Chemists". $15^{\text {th }}$ Ed., Arlington, Virginia 22201: 877-878.

Banon, S.; Ochoa, J.; Fernandez, J.A.; Sanchez, J.J.; Franco, J.A. and Gonzalez, A. (2003). Plant growth retardants for introduction of native Reichardia tingitana. Acta Hort.,598:271-277.
Basra, A.S. (2000). Plant Growth Regulators in Agriculture and Horticulture, Their Role and Commercial Use. Food Products Press, New York, p:264

Bonacin, G.A.; Rodrigues, T. and Mattiuz, C.F. (2006). Aplicacao de retardadores de crescimento em hibridos de girasrol ornamental. Revista Brasileira de Hort. Ornam., 12(1):37-42.

Briggs, J.B. (1975). The effect on growth and flowering of the chemical growth regulator ethephn of Narcissus and ancymidol on tulip. Acta Hort., 47:287 296.

Cuquel, F.L.; Sabbagh, Maria C. and Barneche de Oliveira, Ana, C. (2010). Control of ornamental sunflower height with daminozide. Semina: Ciencias Agrarias, Londrina, 31(1):1187-1192. 
Currey, C.J. and Lopez, R.G. (2008). Applying plant growth retardants for height control. Purdue Dept. Hort. and Landscape Archit., www.Hort.Purdue.edu.

Dole, J.M. and Wilkins, H.F. (1999). Hibiscus, In: Floriculture: Priciples and Spesies. Prantice Hall, Upper Saddle River, N.J., p: 368-372.

Dubois, M.; Smith, F.; Illes, K.A.; Hamilton, J.K. and Rebers, P.A. (1966). Colorimetric method for determination of sugars and related substances. Ann. Chem., 28(3):350-356.

Gianfaga, T.J. (1995). Natural and synthetic growth regulators and their use in horticultural and agrono. mic crops, $\mathrm{p}$. 614-635. In: P.J. Davies (ed.) Plant hormonen: Phsiology, Biochemistry, and Molewlar Biology. $2^{\text {nd }}$ ed. Martinus Nijhoff Publ., Dodrecht, Netherland.

Giuffrida, F.; Cassaniti, C. and Leonardi, C. (2009). Effects of cultivation practices on sunflower production as cut flower. Acta Hort., 807(2):699-704.

Jackson, M.L. (1973). Soil Chemical Analysis. Prentice Hall of India Private Limited M-97, New Delhi, India, 498 pp.

Kazaz, S.; Askin, M.A.; Kilic, S. and Ersoy, N. (2010). Effects of day length and daminozide on the flowering, some quality parameters and chlorophyll content of Chrysanthemum morifolium Ramat. Sci. Res. and Essays, 5(21):32813288.

Kessler, J.R. and Keever, G.J. (2007). Plant growth retardants affect growth and flowering of Coreopsis verticillata "Moonbeam". J. Envirn. Hort., 25(4):229-233.

Khuankaew, T.; Ohyama, T. and Ruamrungsri, S. (2009). Effects of ethephon application on growth and development of Curcuma alismatifolia Gagnep. Bull. Fac. Agric. Njigata Univ., 62(1):9-15.
Kidd, H. and James, D.R. (Eds.) (1991). The Ag. ochemi-cals Handbook, Third Edition. Royal society of Chemistry Information Services. Aeta Hort., 405:351-355.

Kofidis, G.; Giannakoula, A. and Ilias, I.F. (2008). Growth, anatomy and chlorophyll fluorscence of coriander plants (Coriandrum sativun L.) treated with prohexadione-calcium and daminozide. Acta Biologica. Cracoviensia, 50(2):5562.

Krause, J.; Krystyniak, E. and Schroeter, A. (2003). Effect of daminozide on growth and flowering of bedding plants. J. Fruit and Ornam. Plant Res., 11:107-112.

Latimer, J.G. (2001). Selecting and Using Plant Growth Regulators on Floricultural Crops. Virginin Cooperative Extension, Virgiana, USA.

Luatanab, F.S. and Olsen, S.R. (1965). Test of an ascorbic acid method for determining phosphorus in water and $\mathrm{NaHCO}_{3}$ extracts from soil. Soil Sci. Soc. Amer. Proc., 29:677-678.

Mansuroglu, S., Karaguzel, O.; Ortaeesme, V. and Sayan, M.S. (2009). Effect of paclobutrazol on flowering, leaf and flower colour of Consolida orientalis Pak. J. Bot., 41:2323-2332.

Menhennet, R. (1980). Evidence that daminozide but not two other growth retardants, modifies that rate of applied gibberellin A9 in Chrysanthemum morifolium Ramat. J. Expt. Bot. 31:16311642.

Mushtaq, B.A.; Tahir, I.; Shahri, W. and Islam, S.T. (2011). The effect of cycocel and daminozide on some growth and flowering of Calendula officinalis L., an ornamental and medicinal plant. Journal of Plant Sci., 6(2):95-101.

Pregl, F. (1945). Quantitative Organic Micro-Analysis, $4^{\text {th }}$ Ed., J \& A., Churchill, Ltd., London, p: 203-209. 
Rademacher, W. (1995). Growth retardants: Biochemical feature and applicatons in horticulture. Acta Hort., 394:57-73.

Sabbagh, Maria C.; Cuquel, F.L.; Braneche de Oliveira, Ana C. and Guerra, E.P. (2008). Size production of ornamental sunflowers by the application of daminozide. Proc. $17^{\text {th }}$ Inter. Sunflower Conf., Cordoba, Spain, p: 305-307.

SAS, Institute. (2009). SAS/STAT User's Guides Statistics. Vers. 6.04, $4^{\text {th }}$ Ed., SAS Institute Inc., Cary, N.C., USA.

Singh, A.K. (2004). Response of pot marigold (Calendula officinalis) to plant growth regulators. Ind. J. Agric. Sci., 74: 130-132.

Steel, R.G.D. and Torrie, J.H. (1980). Principles and Procedures of Statistics. McGrow Hill Book Co., Inc., New York, p: 377-400.

Takeno, K.; Legge, R.L. and Pharis, R.P. (1981). Effect of the growth retardant B9 (SADH) on endogenous GA level, and transport and conversion of exogenously applied $\left[{ }^{3} \mathrm{H}\right] \mathrm{GA}_{20}$ in Alska pea. Plant Physiology, 67 (suppl):581 (Abst.).

Warner, R.M. and Erwin, J.E. (2003). Effect of plant growth retardants on stem elongation of Hibiscus species. HortTech., 13(2):293-296.

Whipker, B.E.; McCall, I.; Gibson, J.L. and Cavins, T.J. (2004). Flurprimidol foliar sprays and substrate drenches control growth of "Pacino" pot sunflowers. Hort. Technology, Alexandria, 14(3):411-414.

William, M.; Chichlilo, P.; Clifford, P.A. and Reynolds, M. (1965). Official Methods of Analysis of the Association of Official Agriculture Chemists, $10^{\text {th }}$ Ed., Washington D.C. 2004, 4:52-55.

Yadava, Y.L. (1986). Rapid and nondestructive methods to determine chlorophyll in intact leaves. HortScience, 21:1449-1450.

\section{"Sunrich Orange تأثثر بعض مثبطات النمو على نمو وإزهار نباتات عباد الشمس (صنف Summer 981V) أـ ثأثثير معاملات الرش الورقى بالأنسيميدول، الدامينوزايد والإيثيفون}

$$
\text { قسم بحوث الزينة وتنسيق الحدائق، معهد بحوث البساتين، مركز البنحم البحوث الزر اعية، الجيزة، مصر. }
$$

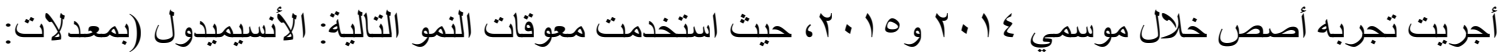

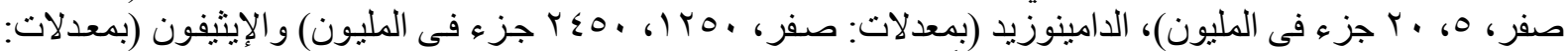

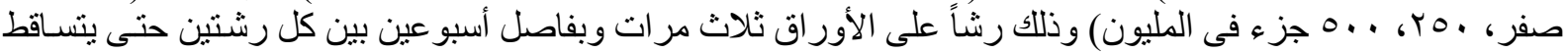

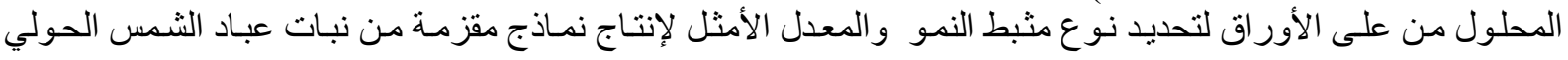
.(Helianthus annuus L. cv. Sunrich Orange Summer 981V)

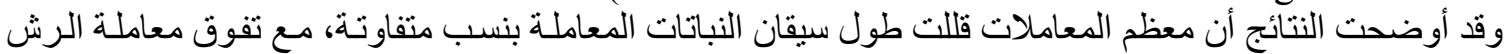

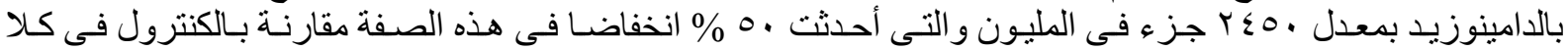

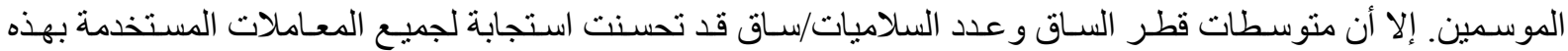

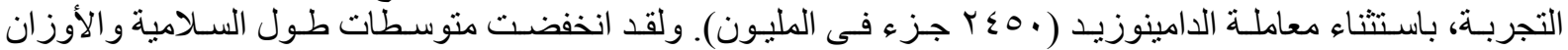

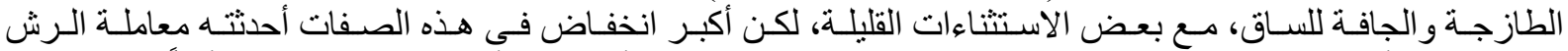

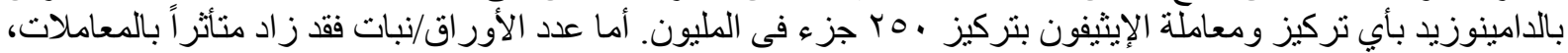

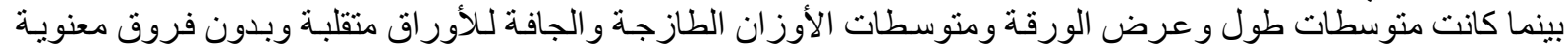

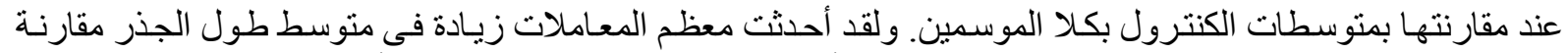

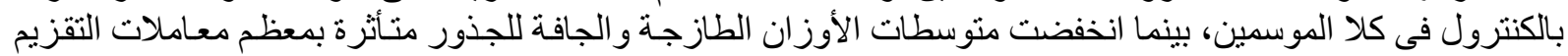

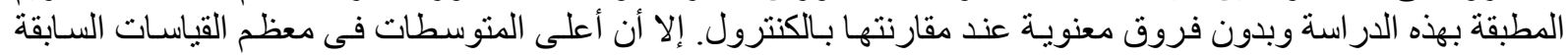




\section{Azza M. Abdel-Moniem}

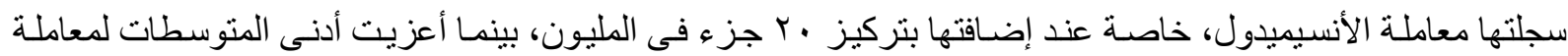

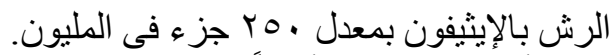

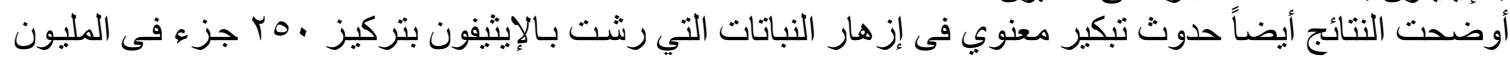

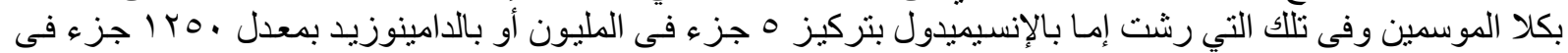

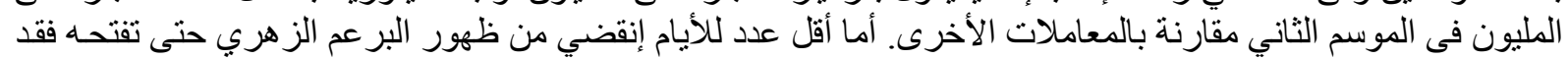

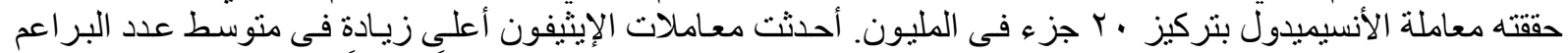

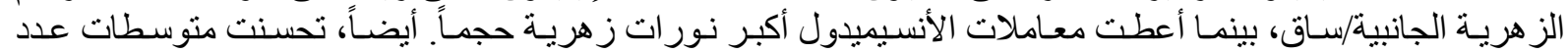

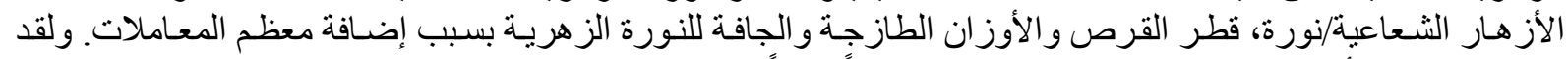

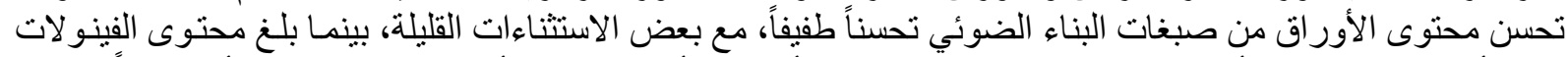

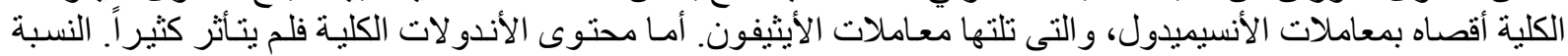

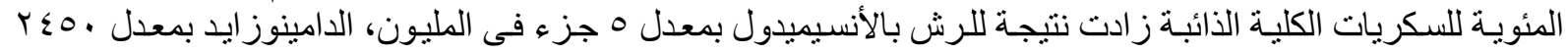

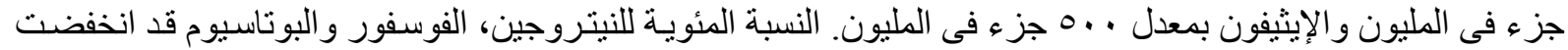
بصفة عامة استجابة لمختلف المعاملات المستخدمة عند المقارنة بالكنترول. 